\title{
Comparison of duodenal flow and digestibility in fauna-free sheep inoculated with Holotrich protozoa, Entodinium monofauna or total mixed protozoa population
}

\author{
M. Ivan* \\ Dairy and Swine Research and Development Centre, Agriculture and Agri-Food Canada, 2000 College Street, PO Box 90 STN \\ Lennoxville, Sherbrooke, Quebec, Canada J1M 1 Z3
}

(Received 12 July 2007 - Revised 31 January 2008 - Accepted 20 March 2008 - First published online 4 September 2008)

The present results are the last part of a series of experiments conducted in this laboratory on metabolism of major individual rumen ciliate protozoa species and their combinations in sheep. These species were inoculated into the rumen of fauna-free (FF) sheep to study digestibility of dietary fibre and duodenal flow of N. Sixteen rumen- and duodenum-cannulated FF sheep were divided into four equal groups and used in the present experiment. One group remained FF, while the other three were each inoculated intraruminally with the Holotrich protozoa sp. (HT), Entodinium sp. (EN) or total mixed fauna (TF). In comparison with the FF group, the HT did not affect $(P>0.05)$ the duodenal flow of non- $\mathrm{NH}_{3}-\mathrm{N}$ and bacterial-N, while the flow was decreased $(P<0.05)$ by both the EN and TF populations. The digestibility of fibre was increased $(P<0.05)$ by both the EN and TF populations, but the results for the HT group were mostly similar to those for the FF sheep. The fibre digestibility in the stomach for TF was intermediate between that for EN and FF. It was concluded that except when fed high-carbohydrate diets, the presence in the rumen of the HT protozoa are of no significant value or major detriment to ruminant production.

Holotrich protozoa: Entodinium: Rumen ciliate protozoa: Sheep

It is well established that the presence of mixed protozoa species populations in the rumen have a negative effect on the utilisation of dietary $\mathrm{N}$ by ruminants ${ }^{(1)}$. In comparison with defaunated (all existing protozoa eliminated from the rumen) or fauna-free (FF; protozoa never existed in the rumen) ruminants a number of experiments have shown a decreased flow of non- $\mathrm{NH}_{3}-\mathrm{N}$ (NAN) components from the stomach to the intestinal tract when mixed protozoa populations were present in the rumen ${ }^{(2-5)}$. However, the species of the mixed population that contribute negatively to $\mathrm{N}$ utilisation and to what extent they do was not known. Although a number of studies involved individual species of protozoa such as Entodinium (EN) and Isotricha (IS) ${ }^{(6-9)}$, the effect of these species on the duodenal flow of NAN components has not been measured. Therefore, we conducted a series of experiments in this laboratory on $\mathrm{N}$ metabolism by individual or combinations of ciliate protozoa species (IS, Dasytricha (DS), Polyplastron (PP), Epidinium (EP), Eudiplodinium (EU), EN and total mixed fauna (TF)). These species were established in the rumen of naturally FF sheep which originated from a sheep flock free of rumen ciliate protozoa for several generations ${ }^{(10)}$. The present work concludes the series which commenced with an experimental approach where FF sheep were inoculated stepwise with individual major species of ciliate protozoa and measurements were conducted progressively after each inoculation ${ }^{(11)}$. Since PP cannot coexist with EP and EU in the rumen, and it belongs to a different type of rumen fauna population (type A) than do EP and EU (type B) ${ }^{(12)}$, concomitant measurements of effects of individual and combinations of the above protozoa species were conducted in both the type $\mathrm{A}$ and type $\mathrm{B}$ populations $^{(11)}$. The results showed that each species or combination of species decreased the duodenal flow of bacterial $\mathrm{N}(\mathrm{BN})$ and of NAN, but to a different degree; the effects on the flow of individual cellulolytic species in the type A (PP) and type B (EP, EU) populations are virtually the same. Owing to the above initial experimental approach of the progressive inoculation the effects of certain species or combinations of species could not be precisely established. Therefore, further work was then conducted with individual ciliate protozoa populations that were established in individual groups of FF sheep that allowed direct comparison of results $^{(13,14)}$. Thus the magnitude of the effects on components of the duodenal $\mathrm{N}$ flow were established for IS, DS, EN and TF-type A in sheep fed different diets ${ }^{(13)}$, and for EN and PP in sheep fed a single diet ${ }^{(14)}$. It was found that the decreasing duodenal flow of BN and NAN due to EN was much larger than those of IS or DS ${ }^{(13)}$, but these effects of the cellulolytic

Abbreviations: AA, amino acids; BN, bacterial N; DS, Dasytricha; EN, Entodinium; EP, Epidinium; EU, Eudiplodinium; FF, fauna-free; HT, Holotrich protozoa; IS, Isotricha; NAN, non- $\mathrm{NH}_{3}-\mathrm{N}$; NDF, neutral-detergent fibre; OM, organic matter; PP, Polyplastron; TF, total mixed fauna.

* Corresponding author: Dr Michael Ivan, fax +1 819564 5507, email ivanm@agr.gc.ca 
PP were similar to those of EN, while there was no duodenal protozoal $\mathrm{N}$ flow in PP-monofaunated sheep ${ }^{(14)}$. However, when DS was added to the population of IS monofauna in the initial experiment ${ }^{(11)}$ the flow of duodenal NAN was similar to that of FF sheep and higher than the flow in sheep with IS monofauna or DS monofauna. In the stepwise establishment of individual protozoa species in the rumen protozoa population the existing species might affect the establishment of a new species, and vice versa ${ }^{(11,15)}$. It was hypothesised, therefore, that similar to the differences in effects of PP in previous experiments ${ }^{(11,14)}$ the combined effects of IS and DS might be different when these species are established in the same rumen individually (stepwise) ${ }^{(11)}$ than when established simultaneously as a Holotrich (IS plus DS sp.) protozoa population (HT). Because direct comparison of this population of HT with TF and FF sheep was not made in previous experiments ${ }^{(11,13)}$, there was a lack of conclusive evidence on the relative effects of HT on the duodenal flow of $\mathrm{N}$ components. To alleviate this lack and to complete the overview of the dynamics of effects on the duodenal $\mathrm{N}$ flow of individual ciliate protozoa monofaunas and their combinations it was the objective of the present experiment to compare these effects of HT with EN as one of the species affecting $\mathrm{N}$ metabolism the most ${ }^{(11,13,14)}$, and with TF and FF sheep as controls.

\section{Materials and methods}

All sheep used in the experiment originated from an FF flock $^{(10)}$; thus, ciliate protozoa have never been previously present in the rumen of these sheep. They were cared for according to guidelines of the Canadian Council on Animal Care ${ }^{(16)}$, and the experimental protocol was approved by the Research Centre Animal Care Committee.

Sixteen approximately 1.5 -year-old FF Canadian Arcott sheep (castrated males) were each surgically fitted with rumen $^{(17)}$ and re-entrant duodenal ${ }^{(18)}$ cannulas. The duodenal cannula was placed proximal to the common bile and pancreatic duct. The sheep were used in the present experiment approximately 4 months after cannulation. One group of four sheep remained FF, while the other three groups of four sheep were inoculated intraruminally with the HT, EN and TF protozoal populations as described previously ${ }^{(14)}$. Each group of sheep was housed in individual pens in a separate room and measurements were initiated 2 weeks later in a $25 \mathrm{~d}$ experiment.

Sheep were fed twice daily (500 g DM in each feeding) a maize silage-based diet at 08.00 and 16.00 hours. Drinking water was available continuously. The diet (DM basis) consisted of $(\mathrm{g} / \mathrm{kg})$ : maize silage, 853 ; soyabean meal, 122; Co-iodised salt, 11; monodical (contained $21 \% \mathrm{P}$ and $15 \%$ $\mathrm{Ca}), 4$; limestone, 6; vitamin mix, 1 (4 mg retinol and $30 \mu \mathrm{g}$ $\alpha$-tocopherol); $\mathrm{Cr}_{2} \mathrm{O}_{3}, 3$. The silage was supplemented with soyabean meal to ensure sufficient $\mathrm{N}$ for optimal microbial growth. Chromic oxide was used as a flow marker and together with monodical and vitamin mix was mixed into the soyabean meal, which was then again mixed into the silage as a single batch. The mixed feed was bagged and stored in a cold room. The chemical composition of the diet was (g/ $\mathrm{kg} \mathrm{DM})$ : N, 23; acid-detergent fibre, 234; neutral-detergent fibre (NDF), 413; organic matter (OM), 934.
On day 15 the sheep were placed into individual metabolism cages ${ }^{(19)}$. Faeces, duodenal digesta, and rumen fluid were collected and sampled on days 18 to 19,22 and 23, and 24 and 25 , respectively. A small quantity of the diet was collected at each feeding on days 15 to 25 and accumulated as a sample. The samples were freeze-dried. Concentrations of $\mathrm{Cr}$ in feed and faecal samples were used for calculation of the daily excretion of faeces $(\mathrm{g})=\mathrm{DM}$ intake $(\mathrm{g}) \times($ feed $\mathrm{Cr}(\mathrm{mg} / \mathrm{g}) /$ faecal $\mathrm{Cr}(\mathrm{mg} / \mathrm{g}))$.

Total duodenal digesta were collected on two consecutive days as described previously ${ }^{(11)}$. A $10 \%$ sample was accumulated for each sheep and each sample was subdivided into two parts. One part was centrifuged at $70000 \mathrm{~g}$ and $5^{\circ} \mathrm{C}$ for $30 \mathrm{~min}$ and the other part was freeze-dried. Concentrations of $\mathrm{Cr}$ in feed and digesta samples were used for calculation of the daily digesta flow $(\mathrm{g})=\mathrm{DM}$ intake $(\mathrm{g}) \times($ feed $\mathrm{Cr}(\mathrm{mg} / \mathrm{g}) /$ digesta $\mathrm{Cr}(\mathrm{mg} / \mathrm{g}))$.

Rumen contents $(500 \mathrm{ml})$ were obtained through the rumen cannulas $^{(14)}$ at $0,2,4$ and $6 \mathrm{~h}$ after the morning feeding. The $\mathrm{pH}$ of the rumen contents was measured immediately. Part $(150 \mathrm{ml})$ of the rumen sample was then strained through one layer of cheesecloth. Filtrate $(5 \mathrm{ml})$ was preserved with $5 \mathrm{ml}$ methyl green-formalin-saline solution ${ }^{(20)}$. Preserved samples from the two collection days were combined and used for protozoal counts as described previously ${ }^{(14)}$. The remainder of the contents was strained through two layers of cheesecloth and a $20 \mathrm{ml}$ portion was centrifuged at $70000 \mathrm{~g}$ at $5^{\circ} \mathrm{C}$ for 30 min to obtain the soluble cell-free fraction.

Freeze-dried feed, duodenal and faecal samples were ground to pass through a $1 \mathrm{~mm}$ diameter sieve (Wiley Mill model 4; Thomas Scientific, Swedesboro, NJ, USA) before determining analytical DM, OM, acid-detergent fibre, NDF, $\mathrm{Cr}$ and amino acids (AA). Analytical DM was determined by drying samples at $135^{\circ} \mathrm{C}$ in an oven for $2 \mathrm{~h}$ and followed by hot weighing. All chemical analyses were performed in duplicate in each sample. The OM content was calculated as a difference between 1000 and the $\mathrm{g} / \mathrm{kg} \mathrm{DM}$ of $\mathrm{ash}^{(21)}$. The NDF was determined as described by Van Soest et al. ${ }^{(22)}$, and acid-detergent fibre was determined according to the procedure of the Association of Official Analytical Chemists ${ }^{(21)}$. The Kjeldahl procedure was used for determination of $\mathrm{N}$. The $\mathrm{NH}_{3}-\mathrm{N}$ content in strained rumen fluid and centrifuged duodenal digesta was quantified by the phenol-hypochlorite reaction ${ }^{(23)}$. The NAN content in rumen fluid and duodenal digesta was determined by subtraction of $\mathrm{NH}_{3}-\mathrm{N}$ from total $\mathrm{N}$. Determination of volatile fatty acids in rumen fluid was as described by Erfle et al. ${ }^{(24)}$. Amino acid concentrations in freeze-dried duodenal digesta were measured by an AA analyser (Beckmen Instruments, Palo Alto, CA, USA) after hydrolysis in $6 \mathrm{M}-\mathrm{HCl}^{(25)}$. Concentration of diaminopimelic acid was used for the determination of duodenal flow of BN as described by Ivan et al. ${ }^{(13)}$. The $\mathrm{Cr}$ concentration in dry feed, duodenal digesta and faeces was measured by air and acetylene flame atomic absorption spectrometry after digestion of samples with a mixture of nitric and perchloric acids.

The data were statistically analysed as a completely randomised design using PROC MIXED from SAS (SAS Institute, Inc., Cary, NC, USA) ${ }^{(26)}$ with treatment as the fixed effect. When the treatment effect was significant, an LSD test was used to separate the means. The UNIVARIATE procedure was used to test the data for normality and for 
obvious outliers. Differences were declared significant at $P<0 \cdot 05$.

\section{Results}

\section{Protozoa and rumen fermentation}

There were no protozoa present in any of the sheep of the FF group (Table 1). Similarly, no other than the inoculated protozoa species were found in other groups of sheep, indicating that there was no cross-contamination of protozoa among the experimental groups of sheep. The HT group averaged approximately $0.8 \times 10^{4}$ cells per ml rumen fluid of each the IS and DS species, while the EN group of sheep averaged more than twice as many EN cells (approximately 3 million) compared with the TF group of sheep (approximately 1.5 million), in which the number of EN species formed $98 \%$ of the size of the total mixed protozoa population.

The mean rumen $\mathrm{pH}$ (Table 2) was not affected by the protozoa treatments $(P>0.05)$. The concentration of $\mathrm{NH}_{3}-\mathrm{N}$ in the rumen fluid of the FF group was lower $(P<0.05)$ than that of the HT group, while the concentrations in the fluid of the EN and TF groups were similar $(P>0.05)$ but higher $(P<0.05)$ than in the fluid of the other groups (FF and HT). When the NAN concentration was calculated as a percentage of total $\mathrm{N}$ it ranged between 93.6 (FF) and 86.2 (TF). The NAN concentration in the decreasing order was $\mathrm{FF}>\mathrm{HT}>\mathrm{EN}>\mathrm{TF}$; the differences were significant between the TF and the other protozoa treatments (FF, HT, EN), and between the EN and FF treatments. The solubility of $\mathrm{N}$ in rumen fluid was highest $(16.6 \% ; P<0.05)$ in the EN group and lowest $(8.9 \%)$ in the FF group, but the differences between the FF and HT and between the HT and EN groups were not significant. The proportion of $\alpha$-amino- $\mathrm{N}$ in the total NAN was not affected $(P>0.05)$ by the protozoa treatments. The concentration of total volatile fatty acids and acetate:propionate ratio were not affected $(P>0.05)$ by the protozoa treatments, while the proportions of acetic acid were higher and those of butyric acid were lower for the FF and HT groups than for the EN and TF groups $(P<0 \cdot 05)$. No specific pattern in proportions of other individual volatile fatty acids was apparent.

\section{Duodenal flow}

The duodenal flow of $\mathrm{N}$ components was not different $(P>0.05)$ between the FF group and the HT group (Table 3). There were also no differences $(P>0 \cdot 05)$ between the EN group and the TF group. However, the $\mathrm{BN}$ flow was higher $(P<0.05)$ for the FF and HT treatments than for the other treatments (EN, TF), while the difference between the FF and the HT treatments were not significant. The flow of non-bacterial NAN was higher $(P<0.05)$ for the TF than for the FF treatment, but the differences were not significant among the other treatments (FF, HT, EN). As a percentage of NAN the BN flow ranged between $92.3(\mathrm{FF})$ and $63.9(\mathrm{TF})$ in the decreasing order $\mathrm{FF}>$ $\mathrm{HT}>\mathrm{EN}>\mathrm{TF}$.

The duodenal flows of total AA were similar $(P>0.05)$ for the FF and HT treatments and also for the EN and TF treatments, but the flows for the FF and HT were higher $(P<0.05)$ than those for the EN and TF treatments (Table 4). There were various significant differences among treatments in the flow of individual AA (see Table 4), but no appreciable differences due to treatments were apparent when the flow of individual AA was calculated as a percentage of flow of total AA.

\section{Digestibility}

The coefficient of apparent digestibility of $\mathrm{OM}$ in the stomach was higher $(P<0.05)$ for the EN treatment than for the HT treatment, but the differences among the other treatments were not significant (Table 5). The differences among treatments in the apparent digestibility of acid-detergent fibre were not significant, but the apparent digestibility of NDF for the EN treatment $(0.506)$ was higher $(P<0.05)$ than that for the FF (0.334) and HT $(0 \cdot 343)$ treatments. The differences among other NDF coefficients were not significant. Except for the non-significant difference between the EN and FF treatments in the total tract digestibility of OM, all the digestibility coefficients (OM, acid-detergent fibre, NDF) were higher $(P<0.05)$ for the EN and TF treatments than for the FF treatments.

\section{Discussion}

It was previously shown in one of the experiments ${ }^{(13)}$ in the series conducted in this laboratory ${ }^{(11,13,14)}$ that irrespective of the diet the number of EN cells was much higher in the EN monofaunas than in the TF populations. In the present experiment and as previously reported ${ }^{(27)}$ the number of EN cells was approximately double in the EN monofauna

Table 1. Protozoal population in sheep with different types of rumen fauna (number of cells $/ \mathrm{ml}$ rumen fluid $\times 10^{4}$ )

(Mean values with their standard errors)

\begin{tabular}{|c|c|c|c|c|c|c|c|c|}
\hline & \multicolumn{8}{|c|}{ Treatment } \\
\hline & \multicolumn{2}{|c|}{ Fauna-free } & \multicolumn{2}{|c|}{ Holotrichs } & \multicolumn{2}{|c|}{ Entodinium } & \multicolumn{2}{|c|}{ Total fauna } \\
\hline & Mean & SE & Mean & SE & Mean & SE & Mean & SE \\
\hline Isotricha sp. & 0 & - & 0.84 & 0.163 & 0 & - & - & - \\
\hline Dasytricha sp. & 0 & - & 0.76 & 0.193 & 0 & - & - & - \\
\hline Entodinium sp. & 0 & - & 0 & - & 296 & $43 \cdot 9$ & 143 & $12 \cdot 8$ \\
\hline Other species* & 0 & - & 0 & - & 0 & - & 3 & 0.2 \\
\hline Total cell number & 0 & - & $1 \cdot 61$ & 0.157 & 296 & $43 \cdot 9$ & 146 & $12 \cdot 9$ \\
\hline
\end{tabular}

*Includes Isotricha sp., Dasytricha sp., Polyplastron sp., Diplodinium sp., etc. 
Table 2. The $\mathrm{pH}$, concentrations of nitrogen components and volatile fatty acids (VFA) in rumen fluid of fauna-free (FF) sheep and of sheep inoculated intraruminally with Holotrich protozoa, Entodinium monofauna or total fauna-type A (Mean values with their standard errors)

\begin{tabular}{|c|c|c|c|c|c|c|c|c|}
\hline & \multicolumn{8}{|c|}{ Treatment } \\
\hline & \multicolumn{2}{|c|}{ FF } & \multicolumn{2}{|c|}{ Holotrichs } & \multicolumn{2}{|c|}{ Entodinium } & \multicolumn{2}{|c|}{ Total fauna } \\
\hline & Mean & SE & Mean & SE & Mean & SE & Mean & SE \\
\hline $\mathrm{pH}$ & $6 \cdot 6$ & $0 \cdot 10$ & 6.5 & 0.04 & $6 \cdot 5$ & 0.05 & $6 \cdot 6$ & 0.04 \\
\hline $\mathrm{NH}_{3}-\mathrm{N}(\mathrm{mg} / 100 \mathrm{ml})$ & $9 \cdot 1^{\mathrm{a}}$ & 1.52 & $13 \cdot 6^{b}$ & 0.37 & $20 \cdot 1^{c}$ & $1 \cdot 24$ & $19 \cdot 3^{c}$ & 1.60 \\
\hline NAN (\% total N) & $93 \cdot 6^{\mathrm{a}}$ & 1.30 & $90 \cdot 6^{\mathrm{a}, \mathrm{b}}$ & 0.63 & $90 \cdot 0^{\mathrm{b}}$ & 0.44 & $86 \cdot 2^{c}$ & $1 \cdot 30$ \\
\hline Soluble N (\% total N) & $8 \cdot 9^{\mathrm{a}}$ & 1.49 & $12 \cdot 0^{\mathrm{a}, \mathrm{b}}$ & $1 \cdot 16$ & $16 \cdot 6^{\mathrm{c}}$ & $1 \cdot 17$ & $12 \cdot 8^{b}$ & 0.73 \\
\hline Free $\alpha$-amino-N (\% total NAN) & $1 \cdot 37$ & 0.163 & 1.67 & 0.191 & $1 \cdot 36$ & 0.140 & $1 \cdot 74$ & 0.264 \\
\hline Total VFA $(\mathrm{mmol} / \mathrm{l})$ & $75 \cdot 9$ & $5 \cdot 86$ & $89 \cdot 3$ & 3.41 & 85.5 & $5 \cdot 21$ & $86 \cdot 6$ & 4.53 \\
\hline Acetate:propionate & $4 \cdot 7$ & 0.28 & $4 \cdot 1$ & 0.21 & $4 \cdot 3$ & 0.09 & 4.0 & 0.33 \\
\hline \multicolumn{9}{|l|}{ VFA $(\mathrm{mol} / 100 \mathrm{~mol})$} \\
\hline Acetic acid & $73 \cdot 4^{\mathrm{a}}$ & 0.66 & $70 \cdot 9^{a}$ & 0.76 & $68 \cdot 3^{b}$ & 0.73 & $67 \cdot 8^{b}$ & 1.08 \\
\hline Propionic acid & $15 \cdot 6$ & 0.83 & $17 \cdot 5$ & 0.72 & $15 \cdot 9$ & 0.72 & $17 \cdot 1$ & 0.72 \\
\hline Butyric acid & $7 \cdot 6^{\mathrm{a}}$ & 0.27 & $8 \cdot 0^{\mathrm{a}}$ & 0.25 & $12 \cdot 0^{\mathrm{b}}$ & 0.63 & $11 \cdot 6^{b}$ & 0.41 \\
\hline Isobutyric acid & $1 \cdot 0^{a}$ & 0.06 & $1 \cdot 0^{\mathrm{a}, \mathrm{b}}$ & 0.02 & $1 \cdot 1^{\mathrm{c}}$ & 0.13 & $1 \cdot 1^{\mathrm{b}, \mathrm{c}}$ & 0.05 \\
\hline Valeric acid & $1 \cdot 0$ & 0.08 & $1 \cdot 1$ & 0.01 & $1 \cdot 1$ & 0.06 & 1.0 & 0.03 \\
\hline Isovaleric acid & $1 \cdot 3^{\mathrm{a}}$ & 0.06 & $1.6^{\mathrm{b}}$ & 0.11 & $1 \cdot 6^{\mathrm{a}, \mathrm{b}}$ & 0.07 & $1 \cdot 5^{\mathrm{a}, \mathrm{b}}$ & 0.09 \\
\hline
\end{tabular}

$\mathrm{NAN}$, non- $\mathrm{NH}_{3}-\mathrm{N}$.

a,b,c Mean values within a row with unlike superscript letters were significantly different $(P<0.05)$.

compared with in the TF population. Results from an additional experiment in the series ${ }^{(14)}$ established that the quantitative duodenal flow of bacterial $\mathrm{N}$ for the EN monofauna and the PP monofauna receiving the same diet is virtually identical. This indicates that both ciliate species populations ingest rumen bacteria, and their predatory activity on the bacteria is equal. These species differ, however, in cell size and metabolic activities. Thus PP is much larger and digests cellulose, while EN is a much smaller starch-utilising protozoon ${ }^{(15)}$. It would appear that the main competition of the two ciliate species is that for the bacterial protein. Since in the EN monofauna of the present experiment there was an obvious absence of PP as compared with the TF type A that contains this protozoon, there was probably a double amount of bacterial protein available for ingestion by the EN, hence the double number of this protozoon in the EN monofauna as compared with the TF type A. Since the rumen bacteria predatory activity for other cellulolytic ciliate species $(\mathrm{EP}, \mathrm{EU})$ is similar to that of $\mathrm{PP}^{(14)}$, there is probably a reciprocal competition for the rumen bacterial protein and resulting dynamics of the population growth between EN and all the cellulolytic protozoa in both type A and type B rumen protozoa populations. This is further substantiated by the fact that there were much lesser cell numbers of the cellulolytic protozoa species (PP or EP plus EU) when EN was present in the type A or B complete populations compared with partial populations of both types containing the cellulolytic species but not $\mathrm{EN}^{(11)}$. It should also be emphasised that PP may ingest EN together with bacteria $^{(15)}$ and in this way may contribute to the reduction in the proportion of EN in the TF population.

In the present experiment, the $\mathrm{pH}$, concentrations of total volatile fatty acids and actate:propionate ratio in rumen fluid indicated no major effect on the rumen fermentation by the protozoal populations tested. However, the concentration of $\mathrm{NH}_{3}-\mathrm{N}$ was higher in all three fauna populations (HT, EN, TF) than in FF sheep. Similarly, higher concentrations of $\mathrm{NH}_{3}-\mathrm{N}$ were observed for IS, DS and their combinations in

Table 3. Duodenal flow of nitrogen in fauna-free (FF) sheep and in sheep inoculated intraruminally with Holotrich protozoa, Entodinium monofauna or total fauna-type A (g/kg organic matter intake)

(Mean values with their standard errors)

\begin{tabular}{|c|c|c|c|c|c|c|c|c|}
\hline & \multicolumn{8}{|c|}{ Treatment } \\
\hline & \multicolumn{2}{|c|}{ FF } & \multicolumn{2}{|c|}{ Holotrichs } & \multicolumn{2}{|c|}{ Entodinium } & \multicolumn{2}{|c|}{ Total fauna } \\
\hline & Mean & SE & Mean & SE & Mean & SE & Mean & SE \\
\hline NAN & $27 \cdot 3^{a}$ & $1 \cdot 38$ & $26 \cdot 5^{a}$ & 0.25 & $22 \cdot 1^{\mathrm{b}}$ & $1 \cdot 15$ & $20 \cdot 8^{\mathrm{b}}$ & $1 \cdot 13$ \\
\hline$(\% \mathrm{FF})$ & \multicolumn{2}{|c|}{100} & \multicolumn{2}{|c|}{97} & \multicolumn{2}{|c|}{81} & \multicolumn{2}{|c|}{76} \\
\hline Bacterial N & $25 \cdot 2^{\mathrm{a}}$ & 1.91 & $23 \cdot 6^{a}$ & 0.52 & $17 \cdot 0^{\mathrm{b}}$ & $1 \cdot 22$ & $13 \cdot 3^{b}$ & 1.91 \\
\hline$(\% \mathrm{FF})$ & \multicolumn{2}{|c|}{100} & \multicolumn{2}{|c|}{94} & \multicolumn{2}{|c|}{67} & \multicolumn{2}{|c|}{53} \\
\hline (\% NAN) & \multicolumn{2}{|c|}{$92 \cdot 3$} & \multicolumn{2}{|c|}{89.1} & \multicolumn{2}{|c|}{76.9} & \multicolumn{2}{|c|}{63.9} \\
\hline Non-bacterial NAN & $2 \cdot 1^{a}$ & 0.05 & $2 \cdot 9^{a, b}$ & 0.49 & $5 \cdot 1^{a, b}$ & 0.22 & $7 \cdot 5^{\mathrm{b}}$ & 2.90 \\
\hline$(\% \mathrm{FF})$ & \multicolumn{2}{|c|}{100} & \multicolumn{2}{|c|}{138} & \multicolumn{2}{|c|}{243} & \multicolumn{2}{|c|}{357} \\
\hline
\end{tabular}

NAN, non- $\mathrm{NH}_{3}-\mathrm{N}$.

a,b Mean values within a row with unlike superscript letters were significantly different $(P<0.05)$. 
Table 4. Duodenal flow of total and selected individual amino acids (AA) in fauna-free (FF) sheep and in sheep inoculated intraruminally with Holotrich protozoa, Entodinium monofauna or total fauna-type A ( $\mathrm{g} / \mathrm{kg}$ organic matter intake)

(Mean values with their standard errors)

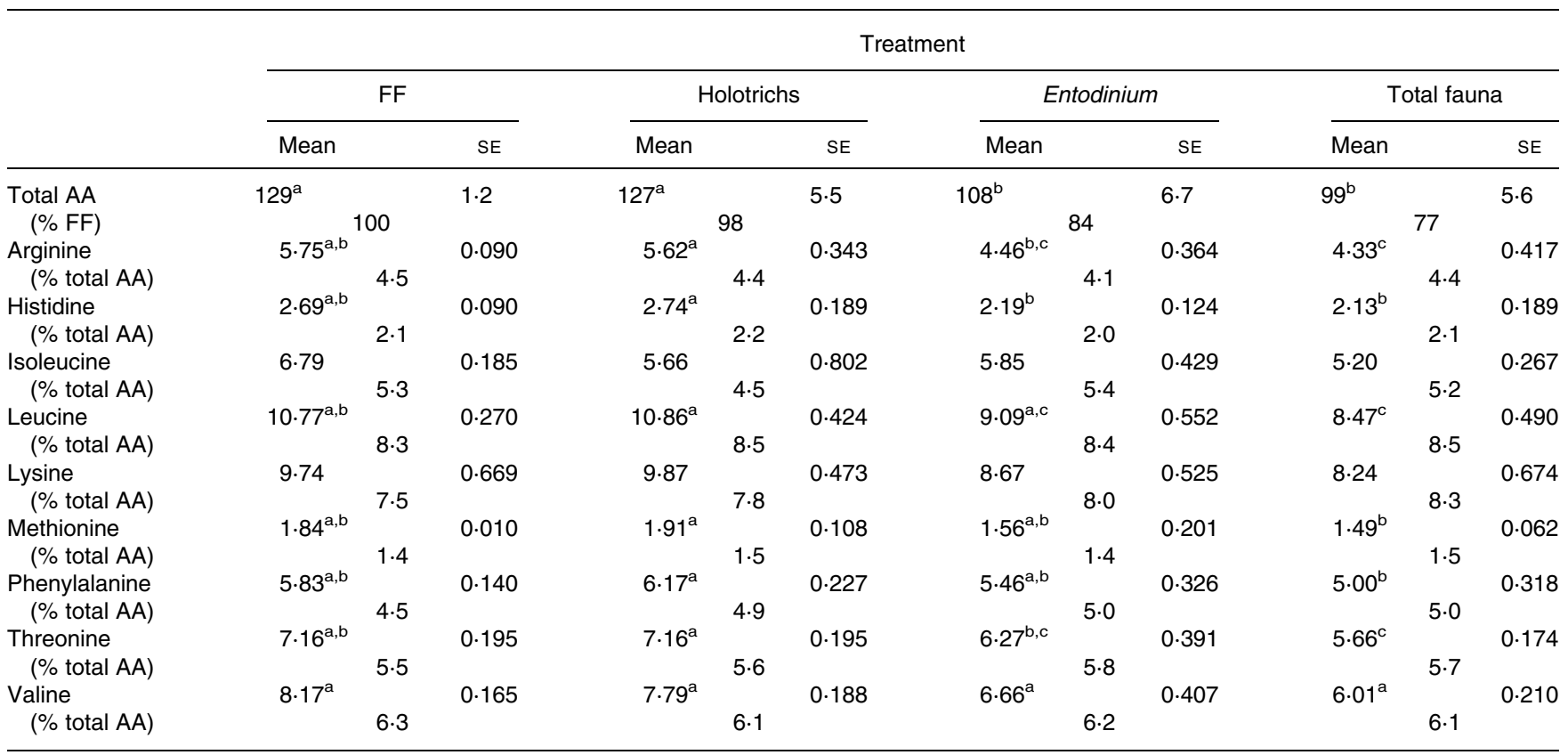

${ }_{\mathrm{a}, \mathrm{b}, \mathrm{c}}$ Mean values within a row with unlike superscript letters were significantly different $(P<0.05)$.

the previous experiments ${ }^{(11,13)}$. This is in agreement with other reports ${ }^{(9,28)}$, but contrary to reports from in vitro and in sacco experiments ${ }^{(8,29,30)}$. These reports noted that the monofaunation of a defaunated rumen in sheep with IS decreased concentrations of $\mathrm{NH}_{3}-\mathrm{N}$ in rumen fluid and the deaminating activity of digesta compared with defaunated or refaunated sheep; it was suggested that IS may increase the by-pass of dietary proteins or peptides from the rumen ${ }^{(31)}$. The differences are probably due to variable negative effects $^{(32)}$ of defaunation technique ${ }^{(33)}$ on rumen bacteria population in the in vitro and in sacco experiments ${ }^{(8,29,30)}$ compared with the use of naturally FF sheep in the present series of experiments. Indeed reported (J-P Jouany, poster presentation, Stara Lesna, Slovakia, 1994) rumen fluid bacteria counts (number $\times 10^{9} / \mathrm{ml}$ ) were $3.4,1.9$ and 1.6 for defaunated, defaunated and refaunated with IS, and defaunated and refaunated with TF-type B, respectively.

The present results clearly show that in comparison with the FF sheep the rumen HT population (IS plus DS) decreased the duodenal flow of NAN and total AA only by 2 and $3 \%$ (not significant statistically), while decreases by the EN monofauna and the TF population were 19 and $16 \%$, and 24 and $23 \%$, respectively. The fact that the presence of $\mathrm{TF}^{(2-4)}$ or $\mathrm{EN}$ monofauna $^{(13,14)}$ decrease the duodenal flow of NAN and/or AA considerably is well known. Previous studies established that ingestion of bacteria and the proteolytic activities of protozoa in the rumen decrease the efficiency of protein utilisation by the ruminant host ${ }^{(4,29)}$. Of the ciliate protozoa

Table 5. Apparent digestibility of organic matter, acid-detergent fibre and neutral-detergent fibre in fauna-free (FF) sheep and in sheep inoculated intraruminally with Holotrich protozoa, Entodinium monofauna or total fauna-type A (g/g intake) (Mean values with their standard errors)

\begin{tabular}{|c|c|c|c|c|c|c|c|c|}
\hline & \multicolumn{8}{|c|}{ Treatment } \\
\hline & \multicolumn{2}{|c|}{$\mathrm{FF}$} & \multicolumn{2}{|c|}{ Holotrichs } & \multicolumn{2}{|c|}{ Entodinium } & \multicolumn{2}{|c|}{ Total fauna } \\
\hline & Mean & SE & Mean & SE & Mean & SE & Mean & SE \\
\hline \multicolumn{9}{|l|}{ Stomach } \\
\hline Organic matter & $0.400^{\mathrm{a}, \mathrm{b}}$ & 0.0010 & $0.396^{b}$ & 0.0420 & $0.520^{\mathrm{a}}$ & 0.0186 & $0.499^{a, b}$ & 0.0371 \\
\hline Acid-detergent fibre & 0.363 & 0.0560 & 0.366 & 0.0381 & 0.472 & 0.0259 & 0.470 & 0.0421 \\
\hline Neutral-detergent fibre & $0.334^{a}$ & 0.0145 & $0.343^{a}$ & 0.0377 & $0.506^{b}$ & 0.0265 & $0.474^{a, b}$ & 0.0651 \\
\hline \multicolumn{9}{|l|}{ Total intestinal tract } \\
\hline Organic matter & $0.681^{a}$ & 0.0150 & $0.735^{a, b}$ & 0.0168 & $0.767^{a, b}$ & 0.0130 & $0.796^{b}$ & 0.0490 \\
\hline Acid-detergent fibre & $0.437^{a}$ & 0.0750 & $0.560^{\mathrm{b}}$ & 0.0216 & $0.610^{\mathrm{b}}$ & 0.0241 & $0.557^{\mathrm{b}}$ & 0.0390 \\
\hline Neutral-detergent fibre & $0.509^{a}$ & 0.0240 & $0.595^{a, b}$ & 0.0249 & $0.659^{b}$ & 0.0180 & $0.612^{b}$ & 0.0348 \\
\hline
\end{tabular}

a,b Mean values within a row with unlike superscript letters were significantly different $(P<0.05)$. 
species in $\mathrm{TF}$, EN are always predominant ${ }^{(6)}$ and ingest bacteria at a high rate $^{(2)}$. But the recent evidence suggests that the decreased protein utilisation by the host is mainly and almost equally due to the presence in $\mathrm{TF}$ of both cellulolytic and EN species ${ }^{(14)}$. In the present experiment the duodenal flow of NAN, BN, non-bacterial-NAN and total AA was similar for EN monofauna and the TF population and in agreement with previous results ${ }^{(13)}$.

The present results on the HT reduction of the NAN flow are in general agreement with the results obtained when DS was superimposed on the existing monofauna of $\mathrm{IS}^{(10)}$. It is, however, evident that these results are similar to those of the IS monofauna, but not to those of the DS monofauna which showed virtually no difference from the FF sheep ${ }^{(13)}$. This appears to be due to the lower bacterial predation, if any, by the DS monofauna compared with the IS monofauna ${ }^{(10,13)}$. It is evident, therefore, that the HT rumen protozoa population consisting of both IS and DS species will result in virtually the same bacterial predation and the duodenal NAN flow as the IS monofauna. It is also evident from the present results that the duodenal flows of total AA for all treatments were similar to those obtained for the flow of NAN, and none of the proportions of the individual AA in the total AA flow were affected by the protozoa treatments (FF, HT, EN, $\mathrm{TF})$. Therefore, bacterial predation by rumen ciliates and the contribution of the ciliate protein do not appreciably affect the AA composition of the duodenal NAN flow. It should be noted, however, that this flow might not contain protein originating from the cellulolytic protozoa species, even though these species are present in the rumen protozoa population ${ }^{(14)}$.

Considering the present results and those from other experiments in the above noted series ${ }^{(11,13,14)}$ it can now be definitively concluded that the HT protozoa engulf only a very small amount of rumen bacteria and, consequently, negatively affect the duodenal flow of NAN to only a small extent. Similarly, the HT protozoa had no appreciable effect on the fibre digestion in the rumen. These protozoa ingest starch grains and soluble carbohydrates and convert them into storage polysaccharide ${ }^{(34)}$. This action prevents alternative bacterial fermentation of these unconverted compounds that would otherwise decrease $\mathrm{pH}$ and increase the onset of lactic acid acidosis. However, these beneficial actions might be limited because lactic acid is also the main endproduct of carbohydrate metabolism by the HT protozoa $^{(15)}$. Furthermore, HT ciliates are significant indirect contributors to the rumen methanogenesis ${ }^{(15)}$. It would appear, therefore, that the presence of the HT protozoa in the rumen ciliate protozoa population is of no value to ruminant production, unless high-carbohydrate diets are used in the feeding system, in which case the presence of the HT protozoa could be beneficial.

The results of the present concluding experiment together with those of the other experiments in the above noted series $^{(11,13,14)}$ established the dynamics of effects of the major rumen ciliate protozoa species on rumen fermentation, digestibility, and duodenal flow of NAN components. The knowledge on these effects is essential to the understanding of how protozoal populations and their major species affect the nutrition of the ruminant host. They are also important in the development of the rumen protozoa-reducing technology to advance the efficiency and to alleviate the environmental impact of ruminant production.

\section{Acknowledgements}

The author wishes to thank T. Entz for the professional statistical analysis of experimental data, L. Neil for technical assistance and R. Moore for the care of experimental animals. All other work associated with the paper was performed by the sole author. The research work was conducted utilising the institutional budgetary financial resources allotted to the author. There are no conflicts of interest.

\section{References}

1. Veira DM (1986) The role of ciliate protozoa in nutrition of the ruminant. J Anim Sci 63, 1547-1560.

2. Coleman GS (1989) Protozoal-bacterial interaction in the rumen. In The Role of Protozoa and Fungi in Ruminant Digestion, pp. 13-27 [JV Nolan, DI Demeyer and RA Leng, editors]. Armidale, NSW: Penambul Books.

3. Ushida K, Jouany JP \& Thivend P (1986) Role of protozoa in nitrogen digestion in sheep given two isonitrogenous diets. $\mathrm{Br}$ J Nutr 56, 407-419.

4. Veira DM, Ivan M \& Jui PY (1983) Rumen ciliate protozoa: effects on digestion in the stomach of sheep. J Dairy Sci 66, $1015-1022$.

5. Ivan M, Hidiroglou M \& Petit HV (1991) Duodenal flow of nitrogen following protozoal inoculation of fauna-free sheep fed a diet supplemented with casein or soybean meal. Can J Anim Sci 71, 793-801.

6. Jouany JP \& Senaud J (1982) Influence des cilies du rumen sur la digestion de differents glucides chez le mouton. I.- Utilisation des glucides parietaux (cellulose et hemicelluloses) et de l'amidon (Effect of rumen ciliates on the digestion of different carbohydrates in sheep. I. - Utilization of cell wall carbohydrates (cellulose and hemicellulose) and of starch). Reprod Nutr Dev 22, 735-752.

7. Jouany JP \& Senaud J (1983) Influence des cilies du rumen sur l'utilisation digestive de différents régimes riches en glucides solubles et sur les produits terminaux formés dans le rumen. II. - Régimes contenant de l'inuline, du saccharose er du lactose (Effect of rumen ciliates on the digestive utilization of various carbohydrate-rich diets and on the end-products formed in the rumen. II. - Utilization of inulin, saccharose and lactose). Reprod Nutr Dev 23, 607-623.

8. Jouany JP, Sénaud J, Toillon S, Ben Salah M, Bohatier J \& Prensier G (1995) Effect of ruminal inoculation of Isotricha alone or a mixed B-type fauna in a defaunated rumen on the digestion of hay-maize diet (70:30) in sheep. Reprod Nutr Dev 35, 11-25.

9. Jouany JP, Zainab B, Senaud J, Groliere CA, Grain J \& Thivend P (1981) Role of the ciliate protozoa Polyplastron multivesiculatum, Entodinium sp. and Isotricha prostoma in the digestion of a mixed diet in sheep. Reprod Nutr Dev 21, 871-884.

10. Ivan M, Veira DM \& Kelleher CA (1986) The alleviation of chronic copper toxicity in sheep by ciliate protozoa. Br J Nutr 55, 361-367.

11. Ivan M, Neill L \& Entz T (2000) Ruminal fermentation and duodenal flow following progressive inoculations of fauna-free wethers with major individual species of ciliate protozoa or total fauna. J Anim Sci 78, 750-759.

12. Eadie JM (1962) Inter-relationships between certain rumen ciliate protozoa. J Gen Microbiol 29, 579-588.

13. Ivan M, Neill L, Forster R, Alimon R, Rode LM \& Entz T (2000) Effects of Isotricha, Dasytricha, Entodinium, and total fauna on ruminal fermentation and duodenal flow in wethers fed different diets. J Dairy Sci 83, 776-787.

14. Ivan M, Koenig KM, Morgavi DP, Rode LM, Newbold CJ \& Entz T (2006) Duodenal flow and digestibility in fauna-free 
sheep and in sheep monofaunated with Entodinium caudatum or Polyplastron multivesiculatum. Br J Nutr 95, 469-476.

15. Williams AG \& Coleman GS (1992) The Rumen Protozoa. New York: Springer-Verlag.

16. Canadian Council on Animal Care (1993) Guide to the Care and Use of Experimental Animals, vol. 1 [ED Olfert, BM Cross and AA McWilliams, editors]. Ottawa, Ontario, Canada: CCAC.

17. Hecker JF (1969) A simple rapid method for inserting rumen cannulae in sheep. Aust Vet J 45, 293.

18. Ivan M \& Johnston DW (1981) Reentrant cannulation of the small intestine in sheep: cannula and surgical method. $J$ Anim Sci 52, 849-856.

19. Ivan M \& Hidiroglou M (1980) The Ottawa plastic metabolism cage for sheep. Can J Anim Sci 60, 539-541.

20. Ogimoto K \& Imai S (1981) Atlas of Rumen Microbiology. Tokyo: Japan Scientific Societies.

21. Association of Official Analytical Chemists (1985) Official Methods of Analysis, 15th ed., Arlington, VA: AOAC.

22. Van Soest PJ, Robertson JB \& Lewis BA (1991) Methods for dietary fiber, neutral detergent fiber, and nonstarch polysaccharides in relation to animal nutrition. J Dairy Sci 74, 3583-3597.

23. Weatherburn MW (1967) Phenol-hypochlorite reaction for determination of ammonia. Anal Chem 39, 971-974.

24. Erfle JD, Mahadevan S \& Sauer FD (1979) Effect of diet quality on adenosine- $5^{\prime}$-triphosphate concentration and adenylate energy charge of rumen microbes from fistulated cows. J Dairy Sci 62, 284-291.
25. Gehrke CW, Wall LL Sr, Absheer JS, Kaiser FE \& Zumwalt RW (1985) Sample preparation for chromatography of amino acids: acid hydrolysis of proteins. AOAC 68, 811-821.

26. SAS Institute Inc. (2005) SAS OnlineDoc ${ }^{\circledR}$ 9.1.3. Cary, NC: SAS Institute Inc.

27. Koenig KM, Ivan M, Teferedegne BT, Morgavi DP, Rode LM, Ibrahim IM \& Newbold CJ (2007) Effect of dietary Enterolobium cyclocarpum on microbial protein flow and nutrient digestibility in sheep maintained fauna-free, with total mixed fauna or with Entodinium caudatum monofauna. Br J Nutr 98, 504-516.

28. Christiansen WC, Kawashima R \& Burroughs W (1965) Influence of protozoa upon rumen acid production and liveweight gains in lambs. J Anim Sci 24, 730-734.

29. Jouany JP, Ivan M, Papon Y \& Lassalas B (1992) Effects of Isotricha, Eudiplodinium, Epidinium + Entodinium and mixed population of rumen protozoa on the in vitro degradation of fish meal, soybean meal and casein. Can J Anim Sci 72, 871-880.

30. Jouany JP (1994) Methods of manipulating the microbial metabolism in the rumen. Ann Zootech 43, 49-62.

31. Jouany JP (1996) Effects of rumen protozoa on nitrogen utilization by ruminants. $J$ Nutr 126, Suppl. 4, 1335S-1346S.

32. Jouany JP, Demeyer DI \& Grain J (1988) Effect of defaunating rumen. Anim Feed Sci Technol 21, 229-265.

33. Jouany JP \& Senaud J (1979) Défaunation du rumen de mouton (Defaunation of the sheep rumen). Ann Biol Anim Biophys 3A, 619-624.

34. Coleman GS (1964) The metabolism of Escherchia coli and other bacteria by Entodinium caudatum. J Gen Microbiol 47, 449-464. 